\title{
Study on coinfecting vector-borne pathogens in dogs and ticks in Rio Grande do Norte, Brazil
}

\author{
Estudo da coinfecção por patógenos transmitidos por vetores em cães e \\ carrapatos no Rio Grande do Norte, Brasil \\ Luiz Ricardo Gonçalves ${ }^{1}$; Kilder Dantas Filgueira ${ }^{2}$; Silvia Maria Mendes Ahid ${ }^{3}$; Josivânia Soares Pereira ${ }^{3}$ André Mendes \\ do Vale ${ }^{3}$; Rosangela Zacarias Machado ${ }^{1}$; Marcos Rogério André ${ }^{*}$ \\ ${ }^{1}$ Departamento de Patologia Veterinária, Faculdade de Ciências Agrárias e Veterinárias - FCAV, Universidade Estadual Paulista - UNESP, \\ Jaboticabal, SP, Brasil \\ ${ }^{2}$ Hospital Veterinário, Universidade Federal Rural do Semi-Árido - UFERSA, Mossoró, RN, Brasil \\ ${ }^{3}$ Laboratório de Parasitologia Animal, Universidade Federal Rural do Semi-Árido - UFERSA, Mossoró, RN, Brasil
}

Received April 25, 2014

Accepted May 23, 2014

\begin{abstract}
Since dogs presenting several vector borne diseases can show none or nonspecific clinical signs depending on the phase of infection, the assessment of the particular agents involved is mandatory. The present study aimed to investigate the presence of Babesia spp., Ehrlichia spp., Anaplasma spp., Hepatozoon spp. and Leishmania spp. in blood samples and ticks, collected from two dogs from Rio Grande do Norte showing suggestive tick-borne disease by using molecular techniques. DNA of E. canis, H. canis and L. infantum were detected in blood samples and R. sanguineus ticks collected from dogs. Among all samples analyzed, two showed the presence of multiple infections with E. canis, H. canis and L. infantum chagasi. Here we highlighted the need for molecular differential diagnosis in dogs showing nonspecific clinical signs.
\end{abstract}

Keywords: CVBDs, co-infection, Ehrlichia canis, Hepatozoon canis, Leishmania infantum, molecular diagnosis.

\section{Resumo}

Cães que apresentam diversas doenças transmitidas por vetores podem mostrar nenhum ou alguns sinais clínicos inespecíficos. Dependendo da fase da infecçấo, a confirmação dos agentes envolvidos é necessária. O presente estudo teve como objetivo detectar a presença de Babesia spp., Ehrlichia spp., Anaplasma spp., Hepatozoon spp. e Leishmania spp. em amostras de sangue e carrapatos, coletados em dois cáes do Rio Grande do Norte. Esses animais apresentavam sinais clínicos sugestivos de doenças transmitidas por carrapatos, quando foram usadas técnicas moleculares. DNA de $E$. canis, $H$. canis e $L$. infantum foram detectados em amostras de sangue e carrapatos $R$. sanguineus coletados dos cáes. Entre todas as amostras analisadas, duas mostraram a presença de infecçóes múltiplas por E. canis, H. canis e L. infantum chagasi. Destaca-se a necessidade de um diagnóstico molecular diferencial em cães com sinais clínicos inespecíficos.

Palavras-chave: DCTVs, coinfecção, Ehrlichia canis, Hepatozoon canis, Leishmania infantum, diagnóstico molecular.

\footnotetext{
*Corresponding author: Marcos Rogério André, Laboratório de Imunoparasitologia. Departamento de Patologia Veterinária, Faculdade de Ciências Agrárias e Veterinárias, Universidade Estadual Paulista - UNESP, Via de Acesso Paulo Donato Castellane, s/n, Zona Rural, CEP 14884-900, Jaboticabal, SP, Brasil, e-mail: mandre.fcav@gmail.com
} 


\section{Introduction}

Ticks are important vectors of pathogens that may affect both animals and humans, causing morbidity and mortality in infected hosts (PAROLA; RAOULT, 2001). Dogs and humans are susceptible to infection by tick-borne agents, which include bacteria, protozoa and viruses. Recently, an increased risk of exposure to tick-borne pathogens among dogs has been observed around the world. Because of the close relationship that these pathogens have to humans, they have become a public health concern (BEUGNET; MARIÉ, 2009).

Among tick-borne diseases affecting dogs, canine monocytic ehrlichiosis (CME) is the most widespread illness reported in Brazil (VIEIRA et al., 2011). It is caused by Ehrlichia canis, an agent belonging to Anaplasmataceae that mainly parasitizes monocytes and is transmitted by Rhipicephalus sanguineus (DUMLER et al., 2001). Canine anaplasmosis is caused by Anaplasma platys and Anaplasma phagocytophilum, which infect dogs' platelets and neutrophils, respectively (DUMLER et al., 2001). Recently, A. phagocytophilum DNA has been detected in blood samples from dogs and in Amblyomma cajennense and R. sanguineus ticks in Rio de Janeiro (SANTOS et al., 2013). A. platys has been molecularly detected in dogs in the states of Mato Grosso do Sul, Paraná, São Paulo and Recife (SOUSA et al., 2013; SILVA et al., 2012; DAGNONE et al., 2009; RAMOS et al., 2010). Although $R$. sanguineus is a potential vector for $A$. platys (INOKUMA et al., 2000), the tick species involved in transmission of $A$. phagocytophilum in Brazil is still unknown.

Canine hepatozoonosis, caused by protozoan parasites belonging to the genus Hepatozoon, is transmitted through ingestion of ticks containing mature oocysts in hemocoel (SMITH, 1996). In Brazil, although Hepatozoon canis has been found parasitizing domestic dogs (MUNDIM et al., 2008; PALUDO et al., 2005), Hepatozoon spp. closed related to Hepatozoon americanum has also been molecularly detected in wild canids (CRIADO-FORNELIO et al., 2006; ANDRÉ et al., 2010). R. sanguineus, Amblyomma ovale and Rhipicephalus (Boophilus) microplus are suspected vectors of H. canis in Brazil (FORLANO et al., 2005; MIRANDA et al., 2011; DEMONER et al., 2013).

Regarding babesiosis, apart from a single report of Babesia gibsoni in a dog from the state of Paraná (TRAPP et al., 2006), dogs are more often affected by Babesia vogeli in Brazil (PASSOS et al., 2005; FURUTA et al., 2009; SOUSA et al., 2013).

Leishmania parasites are predominantly transmitted by Lutzomyia spp. while feeding on blood. Although recent studies have incriminated ticks as suspected vectors of leishmaniasis (DANTAS-TORRES et al., 2010; COLOMBO et al., 2011), the real role of these arthropods in the transmission of Leishmania spp. is still unknown.

Since dogs presenting several vector-borne diseases may only show nonspecific clinical signs, or no signs at all, depending on the phase of infection, it is essential to assess the particular agents involved, given that some of these pathogens (especially A. phagocytophilum and Leishmania spp.) present potential threats to public health.

The present study aimed to investigate the presence of Babesia spp., Ehrlichia spp., Anaplasma spp., Hepatozoon spp. and Leishmania spp. in blood samples and ticks collected from two dogs in Rio Grande do Norte that showed signs suggestive of tick-borne disease, by using molecular techniques.

\section{Materials and Methods}

\section{Blood samples and ticks collected}

Blood samples and ticks were collected from two dogs showing clinical signs of vector-borne diseases that were attended at the teaching hospital of the Federal Rural University of the SemiArid Zone (UFERSA), Mossoró, Rio Grande do Norte, Brazil, in February 2013.

A two-month-old mixed-breed male $\operatorname{dog}(\operatorname{Dog} \# \mathbf{1})$ showed pale mucous membranes, apathy, dry hair, hepatosplenomegaly and presence of ticks on physical examination. This animal had a history of anorexia, vomiting and diarrhea. Although the owner reported having had the animal dewormed, the history of vaccination was not reported. According to the owner during anamnesis, there were no other animals in the same house where the sampled dog was kept. The dog had been acquired 20 days before the date of presentation to the teaching hospital, from a locality in the rural area of the municipality of Mossoró. Hematological and biochemical analyses showed the presence of hypochromic normocytic anemia, anisocytosis, thrombocytopenia, hyperproteinemia and elevated alanine aminotransferase (ALT) and aspartate aminotransferase (AST).

A three-year-old mixed-breed female dog (Dog \#2) showed pale mucous membranes, dry thinning hair, onychogryphosis, scaly skin and crusts, lymphadenomegaly, hepatosplenomegaly and ocular mucous secretion on physical examination. This animal had had a history of hyporexia for approximately 2-3 months, with marked anorexia over the past 3 days, and apathy. According to the owner during anamnesis, although the sampled dog had outdoor access, there were no other animals in the same house where it was kept. Also, although the owner reported that the dog had been vaccinated against rabies, there was no history of deworming. Hematological analysis showed the presence of hypochromic normocytic anemia, anisocytosis, polychromasia, neutropenia, lymphopenia and thrombocytopenia.

\section{Ticks}

A total of seven ticks (three male and one female $R$. sanguineus ticks from Dog \#1; one male and two female $R$. sanguineus ticks from Dog \#2) were collected from the sampled dogs. The ticks collected were placed in tubes with $70 \%$ ethanol and stored at room temperature. After morphological identification as $R$. sanguineus (WALKER et al., 2000), the ticks were subjected to DNA extraction.

\section{DNA Extraction}

DNA was extracted from the dogs' blood samples and from individual ticks using the QIAamp DNA Blood and Tissue Mini Kit (QIAGEN, Valencia, California, USA), in accordance with the manufacturer's instructions. 


\section{DNA Amplification of Ehrlichia spp., Babesia spp., Hepatozoon spp., Anaplasma spp. and Leishmania spp.}

Each sample of extracted DNA was used as a template in $25 \mu \mathrm{L}$ reaction mixtures containing $10 x$ PCR buffer, $1.0 \mathrm{mM}$ of $\mathrm{MgCl}_{2}, 0.2 \mathrm{mM}$ of deoxynucleotide triphosphate (dNTPs) mixture, $1.5 \mathrm{U}$ of Taq DNA polymerase (Invitrogen, Carlsbad, California, USA) with $0.5 \mu \mathrm{M}$ of genus primers for Ehrlichia spp. (16S rRNA gene) (MURPHY et al., 1998), Hepatozoon spp. (18S rRNA gene) (INOKUMA et al., 2002), Babesia spp. (18S rRNA gene) (JEFFERIES et al., 2007), Anaplasma spp. (16S rRNA gene) (MASSUNG et al., 1998), Leishmania spp. (kinetoplast DNA) (MICHALSKY et al., 2002) and L. donovani complex (kinetoplast DNA) (CORTES et al., 2004). Positive controls for Ehrlichia canis and $B$. vogeli DNA were obtained from dogs that had been experimentally infected with Jaboticabal strains of $E$. canis (CASTRO et al., 2004) and B. vogeli (FURUTA et al., 2009), respectively. Hepatozoon sp. and Anaplasma spp. DNA samples were obtained from naturally infected wild and domestic dogs (ANDRÉ et al., 2010; SOUSA et al., 2013). A positive control for Leishmania infantum DNA was obtained from parasites maintained in culturing medium (GenBank: GQ290460) (OLIVEIRA et al., 2011). Ultra-pure sterile water was used as the negative control. In order to prevent PCR contamination, the DNA extraction, reaction setup, PCR amplification and electrophoresis were performed in separate rooms.

\section{Sequencing of PCR products}

The reaction products were purified using the Silica Bead DNA Gel Extraction Kit (Fermentas ${ }^{\circ}$, São Paulo, SP, Brazil). The purified amplified DNA fragments were submitted for sequence confirmation in an automated sequencer (ABI Prism 310 Genetic Analyzer; Applied Biosystems/Perkin Elmer), in house, and were used for subsequent phylogenetic analysis. Consensus sequences were obtained through analysis on the sense and antisense sequences using the CAP3 program (http://mobyle.pasteur.fr/ cgibin/MobylePortal/portal.py). Comparisons with sequences deposited in GenBank were conducted using the basic local alignment search tool (BLAST) (ALTSCHUL et al., 1990). The DNA sequences obtained in the present study were deposited in the GenBank database.

\section{Results}

DNA of E. canis, H. canis and L. infantum was detected in the blood samples and $R$. sanguineus ticks collected from these two dogs with nonspecific clinical signs of tick-borne diseases (Table 1). Both of the dogs were coinfected with at least two pathogens. The $R$. sanguineus ticks collected from both dogs were positive for at least one agent investigated. Among the nine samples analyzed, two of them (Dog \#2 and R. sanguineus male 1") showed the presence of multiple infections with E. canis, H. canis, L. infantum. DNA of Babesia spp. and Anaplasma spp. was not detected in any of the blood and tick samples analyzed. The percentage identicalness and GenBank accession numbers of the DNA sequences amplified from dogs and ticks in the present study are shown in Table 2.

\section{Discussion}

In the present study, we reported on the existence of coinfection by vector-transmitted pathogens in blood samples and ticks collected from dogs showing clinical signs suggestive of arthropodborne diseases. To the authors' knowledge, this is the first report of simultaneous coinfection in dogs and ticks ( $R$. sanguineus) by L. infantum, E. canis and H. canis. In addition, this study shows the first molecular detection of single or multiple infection by L. infantum, E. canis and H. canis in dogs and ticks in the state of Rio Grande do Norte, Brazil.

Recently, multiple vector-borne pathogen infection in dogs showing nonspecific clinical signs has been reported around the world. In the Caribbean region, Kelly et al. (2013) reported coinfection by $A$. platys, E. canis and B. vogeli in 1.1\% (3/279) of the dogs that they sampled in St. Kitts, West Indies. Similarly, Yabsley et al. (2008) detected both A. platys and E. canis DNA in $5.5 \%$ (4/73) of the dogs that they sampled in Grenada. Coinfections

Table 1. Vector-borne pathogens detected molecularly in dogs and ticks in this study, RN, Brazil.

\begin{tabular}{|c|c|c|c|c|c|}
\hline \multirow[b]{2}{*}{ Samples } & \multicolumn{5}{|c|}{ Pathogens } \\
\hline & Anaplasma spp. & Babesia spp. & Ehrlichia canis & Hepatozoon canis & $\begin{array}{c}\text { Leishmania } \\
\text { Infantum }\end{array}$ \\
\hline \multicolumn{6}{|l|}{$\operatorname{Dog} \# 1$} \\
\hline Blood sample & - & - & + & + & - \\
\hline R. sanguineus male 1 ' & - & - & + & - & - \\
\hline$R$. sanguineus male 2 ' & - & - & + & - & - \\
\hline R. sanguineus male 3' & - & - & + & - & - \\
\hline R. sanguineus female 1' & - & - & + & + & - \\
\hline \multicolumn{6}{|l|}{$\operatorname{Dog} \# 2$} \\
\hline Blood sample & - & - & + & + & + \\
\hline R. sanguineus male $1 "$ & - & - & + & + & + \\
\hline$R$. sanguineus female 1 " & - & - & - & + & - \\
\hline$R$. sanguineus female 2 " & - & - & + & - & + \\
\hline
\end{tabular}

( ') ticks collected in the Dog\#1; (") ticks collected in the Dog\#2. 
Table 2. Identity and GenBank accession numbers of sequences amplified from dogs and ticks in the present study, RN, Brazil.

\begin{tabular}{|c|c|c|c|c|}
\hline & & Identity (\%) & & \\
\hline Samples & E. canis & H. canis & L. infantum & Genbank accession numbera \\
\hline \multicolumn{5}{|l|}{$\operatorname{Dog} \# 1$} \\
\hline Blood sample & 100\% (JX437966) & $99 \%(\mathrm{KC} 138535)$ & - & $($ KF972446) ; (KF972441) - \\
\hline R. $s$ male $1^{\prime}$ & $99 \%(J X 437966)$ & - & - & (KF972449) - - \\
\hline R. s. male 2' & $99 \%(J Q 260856)$ & - & - & (KF972447) - - \\
\hline R. s. male 3' & 100\% (JX437966) & - & - & (KF972448) -. \\
\hline R. s. female 1' & 99\% (EU781695) & $99 \%(\mathrm{KC} 138535)$ & - & $($ KF972450) ; (KF972442) - \\
\hline \multicolumn{5}{|l|}{$\operatorname{Dog} \# 2$} \\
\hline Blood sample & $99 \%(J Q 260856)$ & $99 \%(\mathrm{AF} 176835)$ & 99\% (HM179995) & (KF972452) ; (KF972443) ; (KF972455) \\
\hline R. s. male $1 "$ & Not sequenced & - & $97 \%(\mathrm{AF} 169138)$ & - - (KF972453) \\
\hline R. s. female $1 "$ & - & $99 \%(\mathrm{KC} 138535)$ & - & - (KF972444) - \\
\hline R. s. female 2" & $99 \%(J Q 260853)$ & $99 \%(\mathrm{KC} 138535)$ & $99 \%(\mathrm{AF} 169138)$ & (KF972452) ; (KF972445) ; (KF972454) \\
\hline
\end{tabular}

( ') ticks collected in Dog\#1; ( ") ticks collected in Dog\#2; 'Accession numbers deposited in Genbank from this study; Sample (R. s. male 1") was not sequenced for Ehrlichia spp.

by $H$. canis and B. vogeli $(0.89 \%$ [1/89]), H. canis and E. canis (2.67\% [3/89]) and $H$. canis and A. platys (3.56\% [4/89]) were reported in dogs in Buenos Aires, Argentina (EIRAS et al. 2013). In Alto Tras-os-Montes and Douro, in northern Portugal, coinfection by B. canis and L. infantum was reported in $13.3 \%$ (6/45) of the dogs sampled, while multiple infection by B. vogeli, L. infantum and E. canis was found in one $\operatorname{dog}(2.2 \%)$ (CARDOSO et al., 2010). In Naples, Italy, coinfection by E. canis and L. infantum was reported in 79\% (34/43) of the dogs sampled (MEKUZAS et al., 2009). In Brazil, among 60 L. infantum-seropositive dogs sampled in the city of Campo Grande, an endemic area for canine leishmaniasis in the state of Mato Grosso do Sul, Sousa et al. (2013) detected the presence of coinfections between Leishmania sp. and E. canis; Leishmania spp. and B. vogeli; Leishmania sp. and A. platys; and $B$. vogeli and $E$. canis in 22 dogs $(33.6 \%)$, one (1.66\%), one $(1.66 \%)$ and one $(1.66 \%)$, respectively.

Although Anaplasma spp. and Babesia spp. were not molecularly detected in dogs in the present study, these agents have previously been detected in dogs in Brazil. For instance, $A$. phagocytophilum has been detected in dogs and ticks, namely in $R$. sanguineus and A. cajennense, in the state of Rio de Janeiro (SANTOS et al., 2013). On the other hand, $A$. platys has been detected in dogs in the states of Mato Grosso do Sul, Paraná, São Paulo and Recife (SOUSA et al., 2013; SILVA et al., 2012; DAGNONE et al., 2009; RAMOS et al., 2010). B. vogeli is a widespread tickborne hemoprotozoon reported in Brazil (DANTAS-TORRES; FIGUEREDO, 2006).

The occurrence and distribution of these pathogens and their respective diseases in both animals and humans can be correlated with the geographical dispersion of ticks and other arthropod vectors (TROTTA et al., 2012). Multiple pathogens showing zoonotic potential have also been detected in the ticks Ixodes ricinus (A. phagocytophilum, L. infantum and Bartonella henselae) and $R$. sanguineus (Rickettsia conorii, $R$. massiliae, L. infantum and $A$. phagocytophilum) collected from domestic dogs in Europe and South America (TROTTA et al., 2012; PODSIADLY et al., 2007; COLOMBO et al., 2011; SANTOS et al., 2013; SMITH et al., 2013). Dogs parasitized by multiple pathogen-infected ticks may have an unknown clinical outcome that depends on the host-parasite relationship. Studies on interactions between tick-borne agents and Leishmania parasites with regard to establishment and progression of the disease are much needed (SOUSA et al., 2013).

Previously, in the state of Rio Grande do Norte, antibodies to Leishmania spp. were detected in 28\% (39/139) of dogs showing clinical signs of leishmaniasis or asymptomatic dogs that lived in the same area as seropositive dogs (MATOS et al., 2006). Moreover, inclusions suggestive of Ehrlichia spp. were detected in $6.5 \%$ (13/198) of dogs showing clinical signs suggestive of canine monocytic ehrlichiosis (MEDEIROS; LIMA, 2004).

Since dogs infected by Anaplasma spp., E. canis, Leishmania spp., H. canis and/or Babesia spp. show nonspecific clinical signs (fever, weight loss, lethargy, splenomegaly, pale mucous membranes, vomiting and anorexia) and hematological abnormalities (anemia, leukopenia and thrombocytopenia) (CARDOSO et al., 2010; KELLY et al., 2013), a differential diagnosis based on identification of the etiological agents is important, in order to assess the zoonotic potential and the best therapy for the pathogens involved.

Since serological assays show cross-reactions (such as those found between $E$. canis and E. chaffeensis; A. platys and A. phagocytophilum; and Leishmania spp. and Trypanosoma cruzi) and direct detection of these pathogens by means of blood smears shows low sensitivity and specificity, especially in cases of chronic infection or low parasitemia, molecular techniques play a role as an important tool for detection and differentiation of pathogens that infect both animals and humans (LITTLE, 2010; LUCIANO et al., 2009).

\section{Conclusion}

The present work showed the presence of coinfection by multiple arthropod-borne pathogens (L. infantum, E. canis and H. canis) in dogs in Mossoró, state of Rio Grande do Norte, and highlighted the need for molecular differential diagnoses among dogs showing nonspecific clinical signs. 


\section{References}

Altschul SF, Gish W, Miller W, Myers EW, Lipman DJ. Basic local alignment search tool. J Mol Biol. 1990; 215(3): 403-410. http://dx.doi. org/10.1016/S0022-2836(05)80360-2. PMid:2231712

André MR, Adania CH, Teixeira RHF, Vargas GH, Falcade M, Sousa $\mathrm{L}$, et al. Molecular detection of Hepatozoon spp. in Brazilian and exotic wild carnivores. Vet Parasitol. 2010; 173(1-2): 134-138. http://dx.doi. org/10.1016/j.vetpar.2010.06.014. PMid:20630658

Beugnet F, Marié JL. Emerging arthropod-borne diseases of companion animals in Europe. Vet Parasitol. 2009; 163(4): 298-305. http://dx.doi. org/10.1016/j.vetpar.2009.03.028. PMid:19403239

Cardoso L, Yisaschar-Mekuzas Y, Rodrigues FT, Costa A, Machado J, Diz-Lopes D, et al. Canine babesiosis in northern Portugal and molecular characterization of vector-borne co-infections. Parasit Vectors. 2010; 3(1): 27. http://dx.doi.org/10.1186/1756-3305-3-27. PMid:20377861

Castro MB, Machado RZ, de Aquino LP, Alessi AC, Costa MT. Experimental acute canine monocytic ehrlichiosis: clinicopathological and immunopathological findings. Vet Parasitol. 2004; 119(1): 73-86. http://dx.doi.org/10.1016/j.vetpar.2003.10.012. PMid:15036578

Colombo FA, Odorizzi RMFN, Laurenti MD, Galati EAB, Canavez F, Pereira-Chioccola VL. Detection of Leishmania (Leishmania) infantum RNA in fleas and ticks collected from naturally infected dogs. Parasitol Res. 2011; 109(2): 267-274. http://dx.doi.org/10.1007/s00436-0102247-6. PMid:21221638

Cortes S, Rolão N, Ramada J, Campino L. PCR as a rapid and sensitive tool in the diagnosis of human and canine leishmaniasis using Leishmania donovani s.l.-specific kinetoplastid primers. Trans R Soc Trop Med Hyg. 2004; 98(1): 12-17. http://dx.doi.org/10.1016/S0035-9203(03)000026. PMid:14702834

Criado-Fornelio A, Ruas JL, Casado N, Farias NAR, Soares MP, Müller $\mathrm{G}$, et al. New molecular data on mammalian Hepatozoon species (Apicomplexa: Adeleorina) from Brazil and Spain. J Parasitol. 2006; 92(1): 93-99. http://dx.doi.org/10.1645/GE-464R.1. PMid:16629322

Dagnone AS, Souza AI, André MR, Machado RZ. Molecular diagnosis of Anaplasmataceae organisms in dogs with clinical and microscopical signs of ehrlichiosis. Rev Bras Parasitol Vet. 2009; 18(4): 20-25. http:// dx.doi.org/10.4322/rbpv.01804004. PMid:20040204

Dantas-Torres F, Figueredo LA. Canine babesiosis: a Brazilian perspective. Vet Parasitol. 2006; 141(3-4): 197-203. http://dx.doi.org/10.1016/j. vetpar.2006.07.030. PMid:16962707

Dantas-Torres F, Lorusso V, Testini G, de Paiva-Cavalcanti M, Figueredo LA, Stanneck D, et al. Detection of Leishmania infantum in Rhipicephalus sanguineus ticks from Brazil and Italy. Parasitol Res. 2010; 106(4): 857860. http://dx.doi.org/10.1007/s00436-010-1722-4. PMid:20127362

Demoner LC, Rubini AS, Paduan KS, Metzger B, Paula Antunes JMA, Martins TF, et al. Investigation of tick vectors of Hepatozoon canis in Brazil. Ticks Tick Borne Dis. 2013; 4(6): 542-546. http://dx.doi. org/10.1016/j.ttbdis.2013.07.006. PMid:24209494

Dumler JS, Barbet AF, Bekker CP, Dasch GA, Palmer GH, Ray $\mathrm{SC}$, et al. Reorganization of genera in the families Rickettsiaceae and Anaplasmataceae in the order Rickettsiales: unification of some species of Ehrlichia with Anaplasma, Cowdria with Ehrlichia and Ehrlichia with Neorickettsia, descriptions of six new species combinations and designation of Ehrlichia equi and 'HGE agent' as subjective synonyms of Ehrlichia phagocytophila. Int J Syst Evol Microbiol. 2001; 51(6): 2145-2165. http:// dx.doi.org/10.1099/00207713-51-6-2145. PMid:11760958

Eiras DF, Craviotto MB, Vezzani D, Eyal O, Baneth G. First description of natural Ehrlichia canis and Anaplasma platys infections in dogs from Argentina. Comp Immunol Microbiol Infect Dis. 2013; 36(2): 169-173. http://dx.doi.org/10.1016/j.cimid.2012.11.008. PMid:23273677

Forlano M, Scofield A, Elisei C, Fernandes KR, Ewing SA, Massard CL. Diagnosis of Hepatozoon spp. in Amblyomma ovale and its experimental transmission in domestic dogs in Brazil. Vet Parasitol. 2005; 134(1-2): 1-7. http://dx.doi.org/10.1016/j.vetpar.2005.05.066. PMid:16081219

Furuta PI, Oliveira TM, Teixeira MC, Rocha AG, Machado RZ, Tinucci-Costa MG. Comparison between a soluble antigen-based ELISA and IFAT in detecting antibodies against Babesia canis in dogs. Rev Bras Parasitol Vet. 2009; 18(3): 41-45. http://dx.doi.org/10.4322/ rbpv.01803007. PMid:19772774

Inokuma H, Raoult D, Brouqui P. Detection of Ehrlichia platys DNA in brown dog ticks (Rhipicephalus sanguineus) in Okinawa Island, Japan. J Clin Microbiol. 2000; 38(11): 4219-4221. PMid:11060094.

Inokuma H, Okuda M, Ohno K, Shimoda K, Onishi T. Analysis of the 18S rRNA gene sequence of a Hepatozoon detected in two Japanese dogs. Vet Parasitol. 2002; 106(3): 265-271. http://dx.doi.org/10.1016/ S0304-4017(02)00065-1. PMid:12062514

Jefferies R, Ryan UM, Jardine J, Broughton DK, Robertson ID, Irwin PJ. Blood, Bull Terriers and Babesiosis: further evidence for direct transmission of Babesia gibsoni in dogs. Aust Vet J. 2007; 85(11): 459-463. http://dx.doi.org/10.1111/j.1751-0813.2007.00220.x. PMid:17970851

Kelly PJ, Xu C, Lucas H, Loftis A, Abete J, Zeoli F, et al. Ehrlichiosis, babesiosis, anaplasmosis and hepatozoonosis in dogs from St. Kitts, West Indies. PLoS ONE. 2013; 8(1): e53450. http://dx.doi.org/10.1371/ journal.pone.0053450. PMid:23335965

Little SE. Ehrlichiosis and anaplasmosis in dogs and cats. Vet Clin North Am Small Anim Pract. 2010; 40(6): 1121-1140. http://dx.doi. org/10.1016/j.cvsm.2010.07.004. PMid:20933140

Luciano RM, Lucheis SB, Troncarelli MZ, Luciano DM, Langoni H. Avaliação da reatividade cruzada entre antígenos de Leishmania spp e Trypanosoma cruzi na resposta sorológica de cáes pela técnica de imunofluorescência indireta (RIFI). Braz J Vet Res Anim Sci. 2009; 46(3): 181-187.

Massung RF, Slater K, Owens JH, Nicholson WL, Mather TN, Solberg VB, et al. Nested PCR assay for detection of granulocytic ehrlichiae. $J$ Clin Microbiol. 1998; 36(4): 1090-1095. PMid:9542943.

Matos MM, Filgueira KF, Amora SSA, Suassuna ACD, Ahid SMM, Alves ND. Occurrence of visceral leishmaniasis in dogs of Mossoró, Rio Grande do Norte. Ciênc Anim. 2006; 16(1): 51-54.

Medeiros AMM, Lima AKF. Occurrence of canine Ehrlichiosis in Mossoró. Ciênc Anim. 2004; 14(1): 53-57.

Mekuzas Y, Gradoni L, Oliva G, Foglia Manzillo V, Baneth G. Ehrlichia canis and Leishmania infantum co-infection: a 3-year longitudinal study in naturally exposed dogs. Clin Microbiol Infect. 2009;15(S2, Suppl 2): 30-31. http://dx.doi.org/10.1111/j.1469-0691.2008.02150.x. PMid:19416288

Michalsky EM, Fortes-Dias CL, Pimenta PF, Secundino NF, Dias ES. Assessment of PCR in the detection of Leishmania spp in experimentally infected individual phlebotomine sandflies (Diptera: Psychodidae: Phlebotominae). Rev Inst Med Trop Sao Paulo. 2002; 44(5): 255- 
259. http://dx.doi.org/10.1590/S0036-46652002000500004 PMid:12436164

Miranda RL, de Castro JR, Olegário MMM, Beletti ME, Mundim AV, O'Dwyer LH, et al. Oocysts of Hepatozoon canis in Rhipicephalus (Boophilus) microplus collected from a naturally infected dog. Vet Parasitol. 2011; 177(3-4): 392-396. http://dx.doi.org/10.1016/j. vetpar.2011.01.044. PMid:21324597

Mundim AV, Morais IA, Tavares M, Cury MC, Mundim MJS. Clinical and hematological signs associated with dogs naturally infected by Hepatozoon sp. and with other hematozoa: a retrospective study in Uberlândia, Minas Gerais, Brazil. Vet Parasitol. 2008; 153(1-2): 3-8. http://dx.doi.org/10.1016/j.vetpar.2008.01.018. PMid:18304739

Murphy GL, Ewing SA, Whitworth LC, Fox JC, Kocan AA. A molecular and serologic survey of Ehrlichia canis, E. chaffeensis, and E. ewingii in dogs and ticks from Oklahoma. Vet Parasitol. 1998; 79(4): 325-339. http://dx.doi.org/10.1016/S0304-4017(98)00179-4. PMid:9831955

Oliveira TM, de Vasconcelos EJ, Nakaghi AC, Defina TP, Jusi MM, Baldani CD, et al. A novel A2 allele found in Leishmania (Leishmania) infantum chagasi. Rev Bras Parasitol Vet. 2011; 20(1): 42-48. http://dx.doi. org/10.1590/S1984-29612011000100009. PMid:21439231

Paludo GR, Friedmann H, Dell'Porto A, Macintire DK, Whitley EM, Boudreaux MK, et al. Hepatozoon spp.: pathological and partial $18 \mathrm{~S}$ rRNA sequence analysis from three Brazilian dogs. Parasitol Res. 2005; 97(2): 167-170. http://dx.doi.org/10.1007/s00436-005-1419-2. PMid:15988602

Parola P, Raoult D. Tick-borne bacterial diseases emerging in Europe. Clin Microbiol Infect. 2001; 7(2): 80-83. http://dx.doi.org/10.1046/j.14690691.2001.00200.x. PMid:11298147

Passos LM, Geiger SM, Ribeiro MF, Pfister K, Zahler-Rinder M. First molecular detection of Babesia vogeli in dogs from Brazil. Vet Parasitol. 2005; 127(1): 81-85. http://dx.doi.org/10.1016/j.vetpar.2004.07.028. PMid:15619377

Podsiadly E, Chmielewski T, Sochon E, Tylewska-Wierzbanowska S. Bartonella henselae in Ixodes ricinus ticks removed from dogs. Vector Borne Zoonotic Dis. 2007; 7(2): 189-192. http://dx.doi.org/10.1089/ vbz.2006.0587. PMid:17627437

Ramos R, Ramos C, Araújo F, Oliveira R, Souza I, Pimentel D, et al. Molecular survey and genetic characterization of tick-borne pathogens in dogs in metropolitan Recife (north-eastern Brazil). Parasitol Res. 2010; 107(5): 1115-1120. http://dx.doi.org/10.1007/s00436-010-1979-7. PMid:20680344
Santos HA, Thomé SMG, Baldani CD, Silva CB, Peixoto MP, Pires MS, et al. Molecular epidemiology of the emerging zoonosis agent Anaplasma phagocytophilum (Foggie, 1949) in dogs and ixodid ticks in Brazil. Parasit Vectors. 2013; 6(1): 348. http://dx.doi.org/10.1186/17563305-6-348. PMid:24330631

Silva GC, Benitez Ado N, Girotto A, Taroda A, Vidotto MC, Garcia JL, et al. Occurrence of Ehrlichia canis and Anaplasma platys in household dogs from northern Parana. Rev Bras Parasitol Vet. 2012; 21(4) 379-385. http://dx.doi.org/10.1590/S1984-29612012005000009. PMid:23207986

Smith TG. The genus Hepatozoon (Apicomplexa: Adeleina). J Parasitol. 1996; 82(4): 565-585. http://dx.doi.org/10.2307/3283781. PMid:8691364

Smith FD, Elise, L., Wall R. Prevalence of Babesia and Anaplasma in ticks infesting dogs in Great Britain. Vet Parasitol. 2013; 198(1-2): 18 23. http://dx.doi.org/10.1016/j.vetpar.2013.08.026. PMid:24055106

Sousa KC, André MR, Herrera HM, Andrade GB, Jusi MMG, Santos LL, et al. Molecular and serological detection of tick-borne pathogens in dogs from an area endemic for Leishmania infantum in Mato Grosso do Sul, Brazil. Rev Bras Parasitol Vet. 2013; 22(4): 525-531. http://dx.doi. org/10.1590/S1984-29612013000400012. PMid:24473877

Trapp SM, Messick JB, Vidotto O, Jojima FS, Morais HS. Babesia gibsoni genotype Asia in dogs from Brazil. Vet Parasitol. 2006; 141(1-2): $177-$ 180. http://dx.doi.org/10.1016/j.vetpar.2006.04.036. PMid:16765518

Trotta M, Nicetto M, Fogliazza A, Montarsi F, Caldin M, Furlanello T, et al. Detection of Leishmania infantum, Babesia canis, and rickettsiae in ticks removed from dogs living in Italy. Ticks Tick Borne Dis. 2012; 3(5-6): 294-297. http://dx.doi.org/10.1016/j.ttbdis.2012.10.031. PMid:23182545

Vieira RF, Biondo AW, Guimarães AM, dos Santos AP, Santos RP, Dutra LH, et al. Ehrlichiosis in Brazil. Rev Bras Parasitol Vet. 2011; 20(1): 1-12. http://dx.doi.org/10.1590/S1984-29612011000100002. PMid:21439224

Walker JB, Keirans JE, Horak IG. The Genus Rhipicephalus (Acari, Ixodidae): A Guide to the Brown Ticks of the World. New York: Cambridge University Press; 2000.

Yabsley MJ, McKibben J, Macpherson CN, Cattan PF, Cherry NA, Hegarty BC, et al. Prevalence of Ehrlichia canis, Anaplasma platys, Babesia canis vogeli, Hepatozoon canis, Bartonella vinsonii berkhoffi, and Rickettsia spp. in dogs from Grenada. Vet Parasitol. 2008; 151(2-4): 279-285. http:// dx.doi.org/10.1016/j.vetpar.2007.11.008. PMid:18160223 